\title{
PERANAN WANITA DESA SOCO BENDO MAGETAN DALAM MENGATASI DAMPAK PSIKOLOGI SOSIAL PASCA MADIUN AFFAIR 1948 (STUDI SEJARAH SOSIAL)
}

\author{
Muhammad Hanif ${ }^{1}$ )
}

\begin{abstract}
Abstrak
Penelitian ini bertujuan untuk mendapatkan gambaran yang lebih memadai tentang peranan wanitia desa Soco Bendo Magetan dalam mengatasi dampak psikologi sosial pasca Madiun Affair 1948. Penelitian dilakukan selama delapan bulan. Data diperoleh dari sumber materiil berupa sumber lisan/kesaksian laporan tertulis, dan dokumen, serta dari sumber non materiil berupa lembaga sosial, etik, dan tradisi. Penentuan responden dilakukan secara snowball. Teknik pengambilan data dengan wawancara, observasi, dan pencatatan dokumen. Analisis datanya menggunakan analisis kualitatif model interaktif.

Hasil penelitian menunjukkan bahwa Madiun Affait 1948 memodifikasi dan mendistorsi interaksi sosial masyarakat Soco yang hidup rukun dan saling menghargai berubah menjadi interaksi sosial yang penuh prasangka sosial dan sterotip. Dalam situasi seperti itu, kaum wanita mempunyai kemampuan mengontrol nilai-nilai dan mengkomunikasikan secara verbal maupun non verbal. Meski tidak banyak kaum wanita yang dapat mengakses simbol-simbol nilai secara komprehensif, namun simbol-simbol dan nilai-nilai hidup yang adiluhung dapat dienkulturasikan dan disosialisasikan kepada anggota keluarga, terutama anak-anak dan tetangga melalui petuah pendidikan keluarga. Kontak yang semakin intensif dalam memenuhi kebutuhan hidup dan juga perkembangan politik nasional memberi andil dalam mengeliminasi prasangka sosial dan sterotip di Soco Bendo Magetan.
\end{abstract}

Kata kunci: $\quad$ Wanita, Psikologi Sosial, Madiun Affair 1948

1) Muhammad Hanif Dosen Pendidikan Sejarah IKIP PGRI Madiun; Jl Setiabudi 85 Madiun; email: muhhanieff@yahoo.com. 
$64 \mid$ A g a s ty a - Vol. 1, Januari 2011 


\section{Pendahuluan}

PKI dalam gerakan mengkomuniskan Indonesia menggunakan jalan kekerasan, progresif, konfrontatif, dan tidak mengenal kompromi. Gerakan itu dilakukan sebagai upaya pemberontakan terhadap pemerintah yang sah guna mendirikan pemerintahan komunis yang diinginkannya.

Salah satu pemberontakan PKI yang sulit dilupakan orang adalah yang terjadi di Madiun pada September 1948 yang kemudian terkenal dengan sebutan Madiun Affair. Pejabat, prajurit, lurah, pamong praja, kiai, santri, dan masyarakat yang menjadi korban dan suasana saat itu sangat mencekam. Hal tersebut sebagaimana ditulis oleh Tim Jawa Pos, bahwa kejadian itu terasa begitu mengerikan, “... beriburibu manusia dengan kelewang dan berbagai senjata memekik-mekik bagai serigala kehausan darah ... mereka berduyun-duyun tidak ada habisnya sambil terus memekik dan memaki-maki kemudian menerjang dengan beringas dan penuh kebencian." (Tim Jawa Pos, 1990:15). Tidak hanya menelan banyak korban jiwa dan harta, tetapi dampaknya masih terasa hingga sekarang, terutama pada aspek psikologi (sterotip dan prasangka sosial).

Peristiwa PKI 1948 dengan berbagai dampaknya telah banyak dibicarakan dan ditulis, dan begitu halnya dengan masalah wanita, baik oleh pakar dalam negeri maupun luar negeri dengan berbagai dimensi, namun kiranya belum ada yang menyoroti bagaimana peran kaum wanita dalam menangani dampak psikologi sosial pasca Madiun Affair 1948.

Belum adanya penelitian tentang wanita dalam kasus ini tidak lepas dari persoalan umum studi sejarah bangsa Indonesia. Sejarah Indonesia lebih konvensional dengan dipenuhi tema-tema politik dan militer yang secara substansional bercorak androcentris dan memandang wanita sebagai second sex. Kuntowijoyo mengatakan bahwa gambaran masa lalu semacam itu tentu saja tidak adil, karena wanita juga ikut serta dalam dinamika sejarah suatu komunitas (Kuntowijoyo, 2003:113-115). Untuk itu perlu adanya penelitian tentang wanita dengan berbagai dimensi sebagai upaya untuk mendapatkan gambaran masa lalu yang lebih adil. Oleh karena itu, penelitian ini menarik untuk dilakukan.

Adapun masalah yang muncul dalam penelitian ini dapat dirumuskan yaitu: "Bagaimanakah peranan wanita desa Soco Bendo Magetan dalam mengatasi dampak psikologi sosial pasca Madiun Affair 1948 ?"

\section{Tinjauan Pustaka}

Peranan wanita dapat dilihat dari sudut pandang transformasi wanita yang mencakup fungsionalisme dalam feminisme (Fakih, 2003:80-84). Selain itu dapat dilihat juga dari sudut pandang gender 
specifity yaitu mencakup pola-pola perilaku, ekspresi emosional yang secara sosial dapat dipelajari serta digunakan untuk menilai tingkat kewanitaannya dan kepribadian seseorang (Tangdilintin,1991:9). Polapola perilaku maupun ekspresi emosional wanita dapat terungkap melalui tersedia jejak sejarah yang sama dengan bukti-bukti sejarah atau sering pula disebut sumber sejarah (Widja, 1987:37). Sumber sejarah dapat bersifat materiil dan non materiil. Sumber sejarah yang bersifat materiil diantaranya: prasasti, laporan tertulis, dan sebagainya. Sedangkan yang bersifat non materiil diantaranya: lembaga sosial, etik, tradisi, dan sebagainya. Dengan pengecekan secara kritis sumber sejarah tersebut di atas akan membuka wawasan di dalam melihat peranan wanita. Hal senada disampaikan Sendratari (1992:62), bahwa gambaran wanita dapat digali lewat dokumen dan kesaksian pelaku sejarah.

Psikologi dalam konteks penelitian ini berkenaan dengan psikologi sosial. Yang dimaksud psikologi sosial menurut Waston, merupakan studi tentang interkasi manusia, sedangkan menurut Krech, Chruthfield dan Balami, psikologi sosial adalah pengetahuan hubungan perilaku interaksi manusia (dalam Sarwono, 2002:7).

Dari beberapa pendapat di atas dapat ditarik benang merah bahwa psikologi merupakan kajian tentang proses interaksi masyarakat. Dalam arti luas, interaksi mengacu kepada kenyataan bahwa respon seorang individu atau kelompok (isyarat, ucapan atau gerak jasmaniah) merupakan stimulus bagi individu atau kelompok lainnya yang sebaliknya merespon individu atau kelompok pertama (Waseso,1986:3).

Pendapat senada disampaikan Gerungan (1991:57). Ia mengatakan bahwa interaksi sosial merupakan suatu hubungan antara dua atau lebih individu manusia, dimana kelakuan individu yang satu mempengaruhi, mengubah, atau memperbaiki kelakuan individu yang lain, atau sebaliknya. Model dasarnya ialah dwi-tunggal masyarakat dengan PKI dalam suatu kondisi kontak antar stimulus dan antar respon yang berulang-ulang.

Pengaruh dan dampak tekanan individu atau kelompok terhadap individu atau kelompok lain akan selalu memodifikasi dan mendistorsi penilaian individu atau kelompok. Dasar pendekatan mutakhir adalah aksioma, bahwa tekanan kelompok secara mentabiat menyebabkan perubahan psikologis begitu saja, tidak peduli ciri-ciri material kondisikondisinya yang bermuara pada prasangka sosial (social prejudice) dan sterotip. Prasangka adalah sikap negatif terhadap kelompok tertentu atau seseorang, semata-mata karena keanggotaannya dalam kelompok tertentu. Sedangkan yang dimaksud stereotip adalah sifat yang khas yang seakan-akan menempel pada kelompok yang diberikan kelompok lain. Kedua hal itu merupakan problem utama psikologi sosial karena dampaknya pada hubungan antar pribadi dan antargolongan.

Sehubungan dengan hal tersebut di atas, secara alamiah timbul 
sumbang saran yang bertujuan membebaskan para individu dari rintangan, kritik diri oleh individu lain agar dalam menanggapi suatu masalah tertentu mereka dapat menghasilkan gagasan-gagasan lain sebanyak mungkin. Usaha-usaha untuk mengeliminir prasangka sosial dan streotip tidaklah mudah, karena prasangka dan stereotip bersumber pada diri manusia dan interaksi antar manusia, maka tidak dapat sepenuhnya dihilangkan. Namun demikian dapat diatasi atau dikurangi dengan cara menekan sumbernya. Dalam kasus ini yang menjadi sumbernya perasaan ingroup dan outgroup, dan cara mengatasi dengan memperbanyak kontak antar mereka (Sarwono, 2002: 290).

Selain memperbanyak kontak seperti di atas, dapat juga melalui penerangan yang memberi pengertian dan kesadaran mengenai sebab-sebab terjadinya, dipertahankannya, dan mengenai kerugian prasangka sosial dan stereotip bagi masyarakat sebagai keseluruhan dan bagi anggota-anggotanya (Gerungan, 1991: 177). Asumsinya bahwa semakin banyak gagasan yang dihasilkan, semakin besar pula kemungkinan tercapainya suatu pemecahan secara efektif. Menurut Waseso (1986:133-134) sumbang saran itu bercirikan 4 pokok, yakni: kritik dikesampingkan, diterima dengan senang hati, kuantitaslah yang dicari, dan kombinasi dan perbaikan harus ditemukan.

Dalam menangani masalah prasangka sosial perlu dilaksanakan secara komprehensif dari berbagai pihak, termasuk kaum wanita. Menurut Parson (dalam Sarwono, 2002:169), pada umumnya kepribadian yang diharapkan dari wanita berdasarkan norma baku yang berlaku dimanapun yakni baik hati, senang mengasuh, suka bekerja sama, dan peka terhadap perasaan orang lain (Parson dalam Sarwono, 2002:169). Dengan demikian sangat terbuka kaum wanita memainkan peran dalam menangani masalah tersebut.

\section{Tujuan dan Manfaat Penelitian}

Tujuan penelitian ini adalah untuk mendapatkan fakta yang objektif tentang peranan yang dimainkan kaum wanita dalam mengatasi dampak psikologi sosial pasca Madiun Affair 1948, termasuk didalamnya untuk mengetahui kondisi-kondisi di sekeliling wanita dalam menjalankan peranannya.

Langkah ini penting dilakukan sebagai wujud kesediaan peneliti untuk menilai eksistensi kaum wanita, bersedia menarik pelajaran dari peristiwa tersebut, serta menjadi bekal dalam menyusun sikap, kebijakan, dan perilaku sekarang dan masa yang akan datang.

Hasil penelitian ini diyakini dapat bermanfaat bagi beberapa pihak, yaitu:

1. Bagi Program Studi Pendidikan sejarah FPIPS IKIP PGRI Madiun, hasil penelitian ini akan sangat berguna dalam pengajaran sejarah kontemporer dan sejarah lokal. 
2. Bagi masyarakat, terutama para generasi muda, penelitian ini dapat memberikan gambaran tentang Pemberontakan PKI 1948 di Madiun, masalah gender dan tranformasi nilai, serta dimungkinkan dapat meningkatkan kesadaran sejarah.

3. Bagi pemerintah, khususnya Pemerintah Daerah dapat dijadikan bahan untuk mengambil kebijakan dalam pembangunan baik fisik maupun mental, terutama yang berkaitan dengan masalah gender.

\section{Metode Penelitian}

Mengingat penelitian ini merupakan penelitian sosial-historis, maka peneliti menggunakan Metode Hermenutika-Mendalam Thomson (Thomson, 2004). Dipilihnya metode karena penelitian tidak hanya serentetan objek dan peristiwa yang akan diteliti dan dijelaskan, tetapi juga domain subjek yang dirancang sebagai subjek yang dalam rutinitas kehidupan sehari-hari secara konstan berada dalam pemahaman dirinya dan orang lain dalam menghasilkan tindakan dan ekspresi yang bermakna serta dalam menafsirkan tindakan dan ekspresi yang bermakna yang dilakukan oleh orang lain.

\section{Tempat dan Waktu Penelitan}

Penelitian ini dilakukan di Desa Soco Kecamatan Bendo Kabupaten Magetan. Dipilihnya desa ini sebagai tempat penelitian karena desa ini merupakan salah satu basis Pem- berontakaan PKI 1948. Sedangkan waktu penelitian yang digunakan 8 bulan (Maret-Oktober 2006).

\section{Sumber Data Penelitian}

Sumber data yang digunakan dalam penelitian ini sumber sejarah yang bersifat materiil dan non materiil. Sumber sejarah yang bersifat materiil diantaranya: sumber lisan/kesaksiam, laporan tertulis, dan dokumen. Sedangkan yang bersifat non materiil diantaranya: lembaga sosial, etik, dan tradisi.

\section{Responden}

Mengingat responden diketahui secara pasti, maka penentuan respondennya peneliti menggunakan snowball sampling.

\section{Pengambilan Data}

Pengambilan data peneliti menggunakan teknik wawancara, observasi, dan pencatatan dokumen.

\section{Analisa Data}

Mengingat penelitian bersifat sosial-historis, maka bentuk-bentuk peran tidak berada dalam suasana yang vakum, tetapi ditransmisikan dan diterima dalam kondisi sosial dan historis tertentu sehingga peran yang dimainkan dapat diamati secara tepat akan berbeda dengan dari satu studi ke studi yang lain, bergantung pada objek dan kondisi partikular penelitian. Untuk itu analisa yang dipergunakan adalah analisis kualititatif model interaktif (Miles, 1992) sebagaimana bagan di bawah ini. 


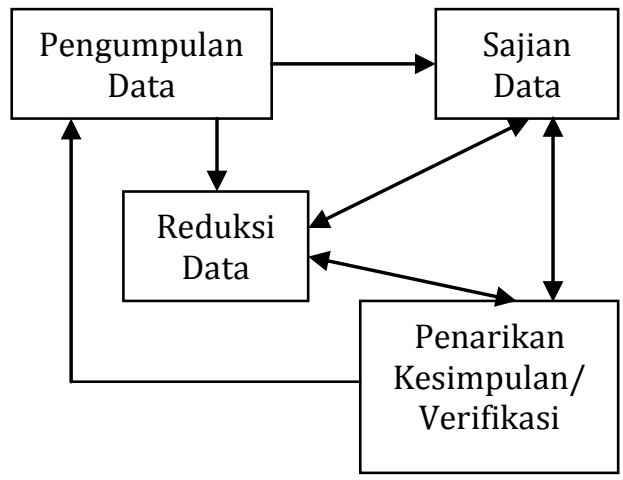

Bagan 1: Analisis Kualitatif Model Interaktif

\section{Hasil Penelitian}

\section{Sekilas Aksi PKI 1948 Di Soco Bendo Magetan}

Soco adalah nama sebuah desa yang letaknya kurang lebih lima ratus meter di sebelah Selatan Lapangan Udara Iswahyudi. Soco termasuk wilayah Kecamatan Bendo Kabupaten Magetan. Desa Soco dalam peristiwa berdarah yang dilakukan oleh FDR/PKI tahun 1948 memiliki arti sejarah tersendiri. Hal ini dikarenakan di desa Soco inilah para tokoh dianggap musuh oleh FDR/PKI dibantai secara masal di dalam sumur-sumur tua di tengah tegalan.

Letak desa Soco cukup strategis, disamping dekat lapangan Udara Iswahyudi, juga dilintasi re-rel kereta Lori dari daerah perkebunan tebu menuju berbagai pabrik gula seperti pabrik gula Pagotan, Kanigoro, Glodok dan Pabrik gula Rejosari di Gorang-gareng. Di desa Soco terdapat sumur-sumur tua di temgah tegalan yag sangat memungkinkan untuk dipakai sebagai lubang pembantaian karena letaknya jauh dari pemukiman penduduk.

Sebelum peristiwa berdarah itu terjadi, warga masyarakat desa Soco sudah mulai merasakan adanya aksiaksi yang dilakukan oleh orangorang PKI; pencurian, perampokan dan penculikan berlangsung dengan semena-mena, yang menjadi korban senantiasa orang-orang yang bukan PKI.

Kejadian itu mencapai puncaknya pada tanggal 18 September 1948. Menurut salah seorang saksi bernama Jalim Anshori, pada saat itu beratus-ratus manusia memakai gelang janur di bawah pimpinan Rusdi bergerak menuju rumah Lurah Tanjung Soemoatmodjo sambil berteriak-teriak, "Sayap kanan tutup! Sayap kiri hidup." Setelah berhasil menangkap lurah Tanjung Samoatmojo digiring oleh orangorang PKI ke sunur Soco untuk dibantai. Selanjutnya orang-orang PKI bergerak menuju rumah sakit salah seorang tokoh Nasionalis, setelah tertangkap Sakidi diikat disana. Mendengar suaminya telah dibantai, Nyonya Sadiki segera menyusul ke Soco. Setelah tiba di Soco dia sudah tidak bisa menjumpai suaminya lagi, tetapi dia nekat ingin melihat jenazahnya, namun akhirnya dia juga dibantai dan mayatnya dimasukkan ke dalam sumur itu juga.

Sumur-sumur tua di Soco tersebut dirancang sedemikian rupa oleh PKI dijadikan basis untuk membantai para tokoh yang dianggap lawan, seperti Bupati Magetan Sudibjo, Kapten Soebarin, Jaksa R. Moerti, Muhammad Suhud 
(Ayahanda Kharis Suhud), Kapten Sumarno, Suratatim, KH. Muhammad Noer, serta aparat pamerintah Republik Indonesia lain yang berhasil mereka tawan itu dibantai.

Di Soco terdapat dua buah sumur tua yang dipakai sebagai lubang pembantaian oleh FDR/PKI, dan keduanya terletak tidak jauh dari jalur rel kereta lori pengangkut tebu. Para tawanan yang disekap di Pabrik gula Rejosari secara bergiliran diangkut dengan gerbong lori. Dari jalur Rejosari itulah gerbonggerbong lori diarahkan ke jurusan desa Soco dan desa Cigrok yang merupakan lubang-lubang pembantaian. Menurut seorang saksi bernama Soepardi, pada waktu itu Lurah Belotan yang bernama Darmo melaporkan ke tangsi polisi ikhwal masuknya FDR/PKI di desanya. Beberapa saat kemudian, Soepardi melihat Lurah tersebut beserta cariknya digiring oleh FDR/PKI ke sumur Soco untuk dibantai.

Dari desa Belotan Soepardi kemudian digiring ke Soco dengan diikat tali bambu. Soepardi mengatakan ketika itu dia digiring oleh tiga pemuda yang dikenal sebagai anak GPII yang setelah ditaklukkan FDR/PKI memang memiliki banyak anggota taklukan dari rakyat maupun organisasi lawan mereka. Justru anggota taklukkan itulah yang kelak akan menjadi bumerang bagi FDR/PKI. Sewaktu Soepardi yang digiring FDR/PKI itu tiba di rumah Karto, seorang penduduk Soco, dia mendengar suara letusan senapan. Ternyata Soepardi mengungkapkan kepala seorang polisi bernama Soeharno ditembak.
Istri Soeharno sendiri, ujar Soepardi oleh FDR/PKI kemudian dijadikan juru masak.

Selama disekap di rumah Karto, Soepardi mengatakan sering mendengar gerbong lori yang mengangkut gula lewat didekatnya. Tetapi dia tidak pernah tahu bahwa di dalam gerbong lori itu sebenarnya para tokoh Magetan sedang dibawa ke sumur Soco untuk dibantai. Soepardi berhasil lolos dari sekapan FDR/PKI setelah ada seorang tentara dari Batalyon 520 yang bersamanya mengajak lari. Menurut Soepardi, waktu itu pihak FDR/PKI memang sudah mendapat gempuran dari Siliwangi sehingga penjagaan menjadi kurang ketat. "Kami meloloskan diri bersama Pak Sudarno, Camat Bendo dan beberapa orang yang lain sampai ke Desa Tegal Arum rombongan pelarian itu kemudian berpisah." Soepardi dan rombongan lari ke Barat., sedang camat Sudarno beserta tawanan yang lain seperti Ismangil dan Darman menuju ke arah Kincang tempat istri Sudarno berada.

Lubang pembantaian di Soco sudah ditemukan, tetapi penggalian belum bisa segera dilakukan. Sebab pada tanggal 19 Desember 1948 (atau tiga bulan setelah pemberontakan PKI di Madiun), dengan kekuatan yang mereka miliki, Belanda menghantam daerah-daerah Republik Indonesia dalam aksi militer kedua yang dikenal dengan sebutan Agresi II.

Orang-orang FDR/PKI yang pada waktu itu ditahan di penjara Madiun, Magetan ataupun kota-kota yang dibebaskan oleh Belanda agar 
membuat kerusuhan lagi untuk merongrong kekuatan Republik Indonesia. Orang-orang FDR/PKI yang dibebaskan oleh Belanda tersebut segera melakukan perampokan-peampokan serta pembunuhan-pembunuhan kembali.

Penggalian sumur Soco baru terlaksana pada awaltahun 1950. Ketika itu Lurah Soco bernama Wir Sakat mendapat perintah dari atasan untuk menggali dua sumur tua di desanya yang telah dipakai oleh FDR/PKI sebagai lubang pembantaian. Dalam upaya penggalian itu dikumpulkan sekitar 12 orang penggali yang dibagi dalam dua kelompok.

Salah seorang pelaku sejarah yaitu Karjo Kuret yang ketika itu menjadi penggali sumur Soco, menyatakan bahwa usaha mengangkat para korban dari lubang sumur dilakukan dangan melancak, yakni dangan menggali dua lubang dari dua arah yang berlawanan menuju titik pusat sumur. Cara itu dilakukan agar lebih mudah mengidentifikasi korban. Menurut Karjo Kuret, sebelum penggalian tersebut dilakukan bersama anggota penggali yang lain, dia disuruh berpuasa terlebih dahulu oleh Kiai Sukemi dari Tanjung. Karjo Kuret mengungkapkan bahwa menurut Kiai Sukemi, pekerjaan yang ia lakukan adalah suatu pekerjaan mulia. Di samping itu, orang yang melakukan pekerjaan yang menggali makam seperti itu harus sangat hati-hati agar jangan merusak jenazah. Penggalian lubang pembantaian barlangsung cukup lama karena orangorang yang menggali harus hati-hati agar tidak merusak jenazah. Sumur itu sudah berisi tanah biasa, tetapi pada bagian dalam ada lubang seperti gua. Di situlah mayat-mayat tersebut bertumpuk.

Karjo mengatakan kondisi mayat sudah seperti tape ketela pohon; ada daging dan kulit yang agak kering melekat di tulang-tulang. Kondisi mayat yang seperti tape itu dibenarkan oleh seorang pelaku sejarah yang lain yaitu Suto Kancil yang menjadi anggota penggali sumur pula. Pada waktu jenazah para korban itu diangkat semua tulangtulangnya lepas satu sama lain.

Menurut Karjo Kutet, di lubang sumur Soco pertama menemukan 78 jenazah. Sementara itu, regu Karso Karmun yang bertugas di sumur Soco kedua menemukan 30 jenazah yang kondisinya juga sudah rusak. Kedalaman sumur sekitar 12 meter dan penuh ditumpuki jenazah. Karjo Kuret sendiri juga mendapat ujian lebih lanjut karena tidak lama setelah penggalian, anaknya yang masih bayi meninggal dunia.

Rusaknya jenazah para korban pembantaian di sumur Soco tersebut disaksikan pula oleh seorang saksi yang lain, yaitu Sumarsono Wilis yang terus menunggui pembongkaran sumur itu. Sumarsono mengungkapkan dia melihat jenazah yang tubuhnya masih dibelit sisa-sisa kain sarung merah. Jenazah itu kelihatan seperti mumi, dengan daging mengering dan rambut yang masih melekat di beberapa tempat. Sumarsono merasa tidak ragu-ragu lagi bahwa jenazah itu adalah jenazah ayahnya yang ia kenal betul meski sudah dalam keadaan kondisi seperti mumi. "Tetapi ketika jenazah 
bapak saya diangkat tulang-tulangnya langsung lepas," ujar Sumarsono. Ia selalu teringat pada kejadian menggetarkan itu.

\section{Dampak Psikologi Sosial Pasca Madiun Affair 1948 Di Desa Soco}

Peristiwa Madiun Affair 948 merupakan peristiwa yang tercatat dalam lembaran hitam dalam sejarah bangsa Indonesia pada umumnya dan di desa Soco pada khususnya. Peristiwa tersebut sangat berpengaruh dalam berbagai aspek kehidupan, salah satu diantaranya adalah aspek psikologi sosial. Untuk mengetahui dampak psikologis sosial pasca Madiun Affair PKI 1948 di desa Soco dibedakan dalam dua kelompok, yaitu kelompok sejaman dan kelompok tidak sejaman.

\section{a. Kelompok Sejaman}

Salah seorang saksi dari kelompok sejaman adalah Parto Pangat, pada saat peristiwa itu terjadi dia sebagai kebayan di desa Soco. Menurut Parto Pangat, situasi dan kondisi desa Soco saat peristiwa itu terjadi sangat mencekam karena dikuasi oleh orang-orang PKI. Masyarakat desa Soco benar-benar tidak berdaya dan tidak dapat berbuat apa-apa sama sekali. Masyarakat merasa was-was dan dalam keadaan ketakutan. Apalagi pada saat itu diberlakukan jam malam. Rumah di sekitar sumur harus dikosongkan dan semua lampu harus dimatikan serta dijaga ketat oleh orang-orang PKI. Malam begitu mencekam dan diselimuti rasa takut. Jika teringat peristiwa saat itu, rasa takut masih membekas diperasaannya sampai sekarang.

Salah seorang saksi lain bernama Jalim. Ia juga salah seorang pelaku sejarah. Menurut Jalim, pada saat peristiwa itu terjadi orang-orang PKI juga menangkap para pemuda yang aktif dalam kegiatan keagamaan termasuk yang bersangkutan setelah pulang dari Pondok Pesantren yang tergabung dalam pemuda Islam. Jalim tidak menyadari kalau dirinya termasuk target yang akan dibantai oleh orang-orang PKI. Ia baru mengetahui kalau dirinya termasuk daftar orang-orang yang akan dibantai orang-orang PKI pada tahap ketiga, setelah ia menemukan arsip PKI pada saaat kedatangan Pasukan Siliwangi orang-orang PKI melarikan diri dan tidak sempat mengamankan dokumen penting.

Jalim melihat bahwa pembantaian yang dilakukan oleh PKI 1948 di desa Soco dilakukan dengan sadis saat melihat jejak-jejak pembantaian sungguh mengerikan. Perasaannya pada saat ini terkesan wajar dalam arti merasa takut, hanya pengalaman menakutkan ditahun 1948 itu yang tidak dapat dilupakan. Dalam berinteraksi dengan lingkungan yang bersangkutan tampak lebih komunikatif. Hal ini karena ia sebagai mantan pejabat tinggi Pemerintah dan sebagai Kiai yang menjadi panutan masyarakat serta sebagai narasumber utama dalam manyampaikan informasi tentang Peristiwa PKI 1948 di desa Soco, baik bagi kalangan masyarakat maupun bagi kalangan akademik. Pandangan Jalim tentang ideologi komunis, ideologi komunis jelas-jelas bertentangan 
dengan ideologi Pancasila, oleh karena itu tidak layak diterapkan di Negara Kesatuan Republik Indonesia.

Menurut salah seorang saksi bernama Kaerun, peristiwa PKI 1948 disebutnya "perang kadang" atau perang saudara. Kairun juga menjelaskan PKI pada saat itu memiliki kekuatan yang besar. Mereka bisa berbuat apa saja tanpa ada yang berani melawan, sehingga mereka tega membantai sesama manusia. Orang-orang PKI sungguh kejam dan tidak kenal rasa kasihan kepada sesama. Orang-orang PKI beramairamai menculik tokoh-tokoh masyarakat satu persatu, kemudian dibawa ke sumur Soco untuk dibantai. Jika mengingat peristiwa pada saat itu, perasaan takut belum bisa dilupakan, apalagi kalau melihat lambang "Palu Arit", bayangan peristiwa yang mengerikan itu tidak bisa dilupakan.

Berdasarkan pengakuan dari saksi-saksi sejarah yang sejaman tersebut di atas dapat ditarik benang merahnya bahwa peristiwa pemberontakan PKI 1948 bagi warga masyarakat desa Soco yang sejaman merupakan suatu peristiwa tragis yang tidak dapat dilupakan sampai sekarang. Pengalaman menakutkan pada tahun 1948 yang dilakukan oleh orang-orang PKI yang kejam, biadab dan tidak kenal perikemanusiaan telah menggores perasaan dan ingatan warga masyarakat desa Soco yang sejaman, perasaan takut yang berkepanjangan dan tidak dapat dilupakan menjadi trauma bagi warga masyarakat desa Soco yang mengalami peristiwa di tahun 1948 tersebut. b. Kelompok tidak sejaman

Untuk mengetahui dampak psikologis sosial akibat Madiun Affair 1948 di desa Soco bagi masyarakat yang tidak sejaman, peneliti mengklasifikasikan ke beberapa kelompok, antara lain: kelompok aparat desa, kelompok pendidikan/guru, kelompok alim ulama, kelompok petani, kelompok pelajar.

1) Kelompok Aparat Desa

Menurut Priyono Kepala Desa Soco, peristiwa tragis ditahun 1948 yang dilakukan oleh PKI di desa Soco diperoleh dari orang tua serta membaca buku. PKI dalam mencapai tujuan ternyata menghalalkan berbagai cara seperti perampokan, penculikan dan pembunuhan, terhadap tokoh-tokoh pemerintah, masyarakat, agama. Pembantaian yang dilakukan orang-orang PKI di sumur Soco merupakan perbuatan keji dan tidak mengenal perikemanusiaan. Dengan membayangkan peristiwa yang terjadi di desa Soco pada tahun 1948, sebagai anak bangsa merasa takut dan ngeri oleh karena itu belajar dari pengalaman sejarah sangatlah penting, harus waspada terhadap segala kemungkinan walaupun kita hidup di zaman kebebasan dan keterbukaan, karena PKI bahaya laten. Ia berharap peristiwa-peristiwa yang menakutkan itu tidak terulang lagi selamalamanya khususnya di desa Soco dan di seluruh tanah air Indonesia pada umumnya.

Berdasarkan pengakuan dari kelompok aparat pemeritahan desa yang lain, masalah PKI 1948 masih dianggap sebagai sebagai sesuatu yang rawan dan menakutkan. Secara 
psikologis sosial sebagai manifestasinya dalam pola tingkah laku kehidupan sehari-hari, kelompok aparat bersikap sangat hati-hati dalam berbicara tentang masalah tersebut, karena jika salah salah dalam berbicara mereka merasa takut dianggap sebagai orang PKI. Sehingga demi keselamatan posisinya sebagai aparat sikap keberhatihatinya melahirkan sikap tertutup sehingga terkesan kurang transparan dalam menyampaikan informasi tentang PKI.

\section{2) Kelompok pendidik atau guru}

Perkembangan pendidikan tidak bisa lepas dari situasi dan kondisi masyarakat serta negara, kondisi negara dengan stabilitas yang mantap akan mendorong terselenggaranya Pendidikan dengan baik, situasi masyarakat yang tentram dan damai akan menciptakan akan menciptakan iklim kegiatan belajar mengajar yang tenang dan kondusif, hal ini didasari sepenuhnya oleh para pendidik atau guru di desa Soco.

Peristiwa PKI 1948 di desa Soco secara psikologis sosial berpengaruh pula terhadap para pendidik atau guru di desa Soco. Untuk mengetahui hal tersebut peneliti membagi menjadi dua kelompok antana lain kelompok guru sekolah dasar dan kelompok guru sekolah lanjut tingkat pertama. Menurut salah seorang guru sekolah dasar bernama Kusmiati sebagai seorang guru banyak belajar berbagai hal, termasuk diantaranya tentang pemberontakan PKI 1948 di desa Soco. Ia membayangkan akan peristiwa PKI 1948 di desa Soco secara pribadi sebagai seorang pendidik yang selalu mengajarkan budi pekerti yang luhur pada anak didik. Dalam perasaan ini ada rasa ngeri, perbuatan yang dilakukan orang-orang PKI yang kejam di luar batas perikemanusiaan. Disamping itu, PKI telah merusak pendidikan dan pengajaran dengan menanamkan ide komunisme pada murid-murid yang belum waktunya mengerti politik.

Gambaran ideologi komunis menurut Kusmiati, merupakan ideologi yang merusak tata nilai kehidupan masyarakat. Sebagai warga negara Indonesia dalam pola tingkah laku sehari-hari mencerminkan nilainilai kemanusiaan yang berketuhanan, sedangkan komunis mengajarkan kebebasan yang tidak bertuhan. Oleh karena itu, komunis merupakan faham yang tidak layak berkembang di Indonsia yang berdasarkan Pancasila.

Peristiwa PKI 1948 di desa Soco tidak berpengaruh dalam kegiatan belajar mengajar di Sekolah Dasar. Peristiwa PKI 1948 di desa Soco bisa diambil hikmahnya yang positif untuk mendidik siswa agar berperilaku yang baik sehingga untuk pengajaran bagi siswa akan lebih bermakna. Dalam menjelaskan tentang peristiwa PKI 1948 di desa Soco yang bersangkutan selalu bersikap hati-hati, sebab jika salah menginformasikan tentang masalah tersebut akan berakibat fatal bagi bagi siswa yang orang tuanya menjadi korban kekejaman PKI dan yang orang tuanya terlibat PKI 1948.

Menurut salah seorang Guru SLTP II Bendo yang berlokasi di desa Soco bernama Kasimun, pengetahu- 
annya tentang kekejaman PKI 1948 di desa Soco diperoleh sejak kecil. Dari pengetahuan tersebut diketahui bahwa tindakan yang dilakukan oleh orang-orang PKI pada tahun 1948 dengan membantai sesama manusia merupakan tindakan angkara murka, yang mengakibatkan penderitaan lahir dan penderitaan batin bagi masyarakat desa Soco pada saat itu bahkan sampai pada saat ini masih dirasakan akibatnya, terutama bagi keluarga yang ditinggalkan para korban kekejaman PKI 1948 di desa Soco.

Gambaran tentang ideologi komunis menurut Kasimun, merupakan hal yang tidak baik. Komunis lahir dari dasar histeriomaterialisme yang menghendaki kehidupan manusia bersendi atas milik bersama dan tidak mengenal adanya Tuhan. Hal ini sangat bertentangan dengan Pancasila sebagai pandangan hidup dan falsafah negara Indonesia yang menghendaki manusia sebagai makhluk sosial budaya susila dan makhluk bertuhan. Menurut Kasimun, peristiwa PKI 1948 di desa Soco tidak berpengaruh dalam kegiatan belajar mengajar di sekolah. Dalam proses belajar mengajar guru bersikap positif dengan demikian siswa akan terdorong secara positif pula sehingga siswa akan merasa senang. Informasi yang ditransformasi sedapat mungkin bermakna bagi siswa dalam arti mengandung pengajaran yang bermanfaat bagi siswa. Guru dapat mengatur informasi dalam mentransfer pada siswa dengan jalan mengasosiasikan informasi yang positif sehingga tercipta atmosfer belajar mengajar yang baik. Sikapnya sebagai guru dalam menjelaskan peristiwa PKI 1948 harus hati-hati, sedapat mungkin menekankan pada aspek edukatif yang mampu menumbuhkembangkan pemahaman siswa sebagai subjek didik, dilakukan dengan membangkitkan semaksimal mungkin untuk dapat belajar dari sejarah di masa lampau. Dengan cara demikian akan mengerti kaidah dan makna yang dapat dijadikan bahan berpikir dan berbuat utuk masa kini dan masa yang akan datang.

Berdasarkan penjelasan dari kelompok pendidik atau guru di atas, maka secara psikologis Peristiwa PKI 1948 di desa Soco bagi kelompok pendidik atau guru tidak memperlihatkan adanya perasaan takut, akan tetapi memperlihatkan adanya perasaan tidak senang terhadap peristiwa tersebut, karena perbuatan orang-orang PKI mengakibatkan penderitaan lahir dan penderitaan batin. Gambaran tentang ideologi komunis di mata para guru di desa Soco, ideologi komunis merupakan salah satu ideologi yang tidak baik, karena bertentangan dengan ideologi Pancasila. Hal ini dikarenakan bukan karena alasan ideologi, akan tetapi mengarah pada alasan politis, yakni disebabkan pendidikan politis selama 32 tahun pada masa pemeritahan Orde Baru, antara lain adanya Tap MPRS No. XXV/ MPRS/1996.

Peristiwa PKI di desa Soco tidak berpengaruh terhadap kegiatan belajar mengajar, baik di SD maupun di SLTP, karena sebagai pendidik dapat mengatur informasi dalam mentransfer informasi tersebut 
dengan jalan mengasosiasikan informasi yang positif pada siswa sehingga dapat menciptakan suasana, baik dalam kegiatan belajar mengajar. Sikap para guru dalam menjelaskan tentang masalah PKI 1948 di desa Soco pada siswa, guru bersikap hati-hati, sebab jika salah menginfomasikan tentang peristiwa tersebut akan berdampak negatif pada siswa, yakni bagi siswa yang orang tuanya menjadi korban kekejaman PKI akan membenci siswa yang orang tuanya tersangkut PKI, mengingat banyak para orang tua di desa Soco terlibat PKI.

3) Kelompok Alim Ulama

Salah satu korban dari pembantaian PKI 1948 di desa Soco adalah kaum alim ulama. Kaum alim ulama menjadi target pembantaian orang-orang PKI tahun 1948 di desa Soco karena dianggap lawan utama PKI 1948. Kaum alim ulama merupakan tokoh terdepan dari golongan agama Islam, yang tentu saja merupakan penghalang bagi PKI dalam melancarkan gerakannya.

Menurut salah seorang ulama bernama Warsito, peristiwa PKI 1948 di desa Soco dilakukan oleh orang-orang yang tidak mengenal Tuhan sehingga mereka tega berbuat kejam dan kekejamannya tidak mengenal perikemanusiaan lagi. Mereka adalah orang-orang yang tidak beriman melalaikan ajaran agama yang tidak boleh menyakiti orang lain, apalagi membunuh sesama saudara. Pembantaian yang dilakukan orang-orang PKI tahun 1948 di desa Soco merupakan perbuatan dzalim, baik terhadap masyarakat maupun terhadap agama.
Mereka tidak memikirkan adanya kehidupan setelah mati, yaitu suatu kehidupan dimana manusia akan menerima pembalasan dari hasil perbuatan ketika mereka yang lakukan di dunia. Dengan melihat kenyataan bahwa alim ulama merupakan musuh utama PKI 1948, banyak alim ulama yang dibantai oleh orang-orang PKI di sumur Soco. Mendegar kisah peristiwa itu menjadi takut. Dengan masih adanya rasa dan perasaan takut berarti dalam diri berarti masih ada iman.

Pandangan para alim ulama terhadap peristiwa PKI 1948, peristiwa tersebut merupakan kedzaliman dari kelompok orang-orang kafir, yaitu dzalim pada masyarakat, bangsa, negara serta dzalim pada agama, perbuatan itu merupakan perbuatan yang sangat tercela. Untuk itu PKI jangan diperbolehkan hidup berkembang di Indonesia. Sebagai orang yang beragama, beriman dan bertaqwa pada Tuhan dalam kehidupan sehari-hari hendaknya mencerminkan sikap kehidupan yang terpuji, dengan pola hidup yang wajar bekerja untuk kepentingan duniawi dan beribadat untuk kepentingan ukhrowi, niscaya akan selamat dunia dan akhirat.

Berdasarkan penjelasan di atas terlihat bahwa secara psikololgis sosial peristiwa PKI 1948 di desa Soco bagi kelompok Alim Ulama memperlihatkan masih adanya perasaan takut. Perasaan takut tersebut dimanifestasikan dalam kehidupan sehari-hari untuk hidup yang wajar, selaras, serasi dan seimbang, dalam berpikir dan berbuat untuk kepentingan dunia dan 
akhirat, lebnih mendekatkan diri pada Allah, mempertebal iman, tidak menyukai kejahatan dan mengutuk perbuatan kedzaliman, serta tidak menerima ideologi komunis karena pada dasarnya ideologi komunis bertentangan dengan ajaran agama Islam.

4) Kelompok Petani dan Pedagang

Masyarakat desa Soco mayoritas bermata pencariaan petani dan sebagai pedagang. Hal ini tampak pada data yang peneliti peroleh dari dokumen kantor desa Soco yang menunjukkan bahwa sebagian besar penduduk desa Soco adalah petani. Sektor pertanian merupakan sektor prioritas yang didukung dengan sarana dan praarana yang memadai.

Keadaan masyarakat desa Soco pada saat ini tidak jauh berbeda dengan situasi pada saat terjadinya peristiwa PKI 1948. Oleh karena mayoritas mata pencarian masyarakat desa Soco adalah petani dan sebagai pedagang, maka kelompok ini merupakan salah satu korban perampokan dan penjarahan orangorang PKI, karena orang-orang PKI membutuhkan materi untuk mendukung gerakannya. Menurut salah satu petani muda yang sukses bernama Agus, pengetahuan kekejaman PKI 1948 di desa Soco diperoleh dari cerita dari pada orang tua dan membaca buku, pendapat yang bersangkutan tentang masalah PKI 1948. Peristiwa PKI 1948 di desa Soco merupakan peristiwa tragis yang tidak dapart dilupakan oeh masyarakat desa Soco, karena peristiwa PKI 1948 merupakan malapetaka besar bagi masyarakat desa Soco pada tahun 1948.
Akibatnya menimbulkan banyak korban baik korban harta maupun korban jiwa raga. Perampokan terjadi dimana-mana, situasi yang demikian ini merupakan ulah orangorang PKI yang sengaja membuat kekacauan di desa Soco. Mendengar kenyataaan yang demikian pada saat terjadinya peristiwa tersebut, sungguh merupakan hal yang sangat mengerikan.

Menurut salah seorang pedagang bernama Padi, peristiwa PKI 1948 disebut "Goro-goro, Prahoro", artinya gara-gara atau prahara PKI 1948. Pendapat yang bersangkutan tentang peristiwa PKI 1948 di desa Soco, peristiwa PKI 1948 pada dasarnya merupakan langkah awal PKI untuk merebut kekuasaan pemerintah dengan cara paksa. Oleh karena cara paksa merupakan hal yang tidak baik, maka tindakan yang ditempuhnya merupakan tindakan yang tidak benar pula, yaitu dengan cara membantai para tokoh pemerintah agama dan tokoh-tokoh masyarakat, termasuk para tokoh di desa Soco. Dengan memperhatikan cerita dari para orang tua tentang pembunuhan yang dilakukan oleh orang-orang PKI tahun 1948 di desa Soco, ada perasaan takut, karena jiwa para tokoh pemerintah, tokoh agama dan tokoh masyarakat seperi tidak ada harganya di mata orang-orang PKI. Pendapat Padi tentang ideologi komunis, ideologi komunis merupakan suatu hal yang tidak baik, karena bertentangan dengan tujuan dari para pedagang, sehingga komunis tidak layak hidup di Indonesia.

5) Kelompok Pelajar 
Menurut salah seorang pelajar bernama Ida Setiyawati, cerita tentang peristiwa kekejaman yang dilakukan oleh orang-orang PKI tahun 1948 di desa Soco diperoleh dari orang tua dan membaca buku. Pembunuhan merupakan hal yang menakutkan apalagi disertai dengan penyiksaan seperti yang dilakukan oleh orang-orang PKI 1948 di desa Soco. Perbuatan yang dilakukan orang-orang PKI merupakan perbuatan yang sangat kejam dan sadis. Menurut pengakuannya, jika mendengar cerita kekejaman PKI tahun 1948 di desa Soco perasaannya ngeri dan takut.

Pendapat Ida tentang peristiwa PKI 1948 merupakan tragedi nasional yang dilakukan oleh orang-orang yang ingin mendirikan negara berideologi komunis lepas dari negara kesatuan Republik Indonesia. Ideologi komunis sangat bertentangan dengan ideologi Pancasila. Oleh karena bertentangan Pancasila sebagai dasar dan falsafah negara, maka komunisme merupakan ideologi yang tidak baik untuk diterapkan di Indonesia.

Berdasarkan pengakuan dari kelompok tidak sejaman di atas, terlihat jelas bahwa aksi PKI tahun 1948 di desa Soco menimbulkan ketakutan. Perasaan takut pada warga masyarakat yang tidak sejaman merupakan akibat bayangan dari rangsangan yang dilakukan oleh generasi sejaman dalam arti kata generasi sejaman menurunkan perasaan takut secara langsung pada generasi tidak sejaman atau generasi tidak keturunan.

\section{Peran Wanita Dalam Mengatasi Dampak Psikologi Sosial Pasca Madiun Affair Di Soco Bendo Magetan}

Masyarakat desa Soco, terutama kaum wanita, tidak mengetahui secara persis tentang motif Madiun Afair 1948, namun mereka merasakan ada yang berubah menjelang peristiwa tersebut. Interakasi sosial yang damai dan penuh kerukunan berubah menjadi ketegangan. Prasangka sosial dan sterotip menyelimutinya tatkala mereka berinteraksi di masyarakat.

Kaum wanita tidak menduga PKI akan melakukan tindakan di luar batas kemanusiaan. Yang mereka tahu PKI sering melakukan "perayaan" seperti reog, ketoprak, dan sebagainya. Mereka juga senang dan ikut menontonnya yang tanpa disadari, PKI melakukan kegiatan tersebut hanyalah sebagai media untuk merebut hati masyarakat.

Pasca Madiun Affair 1948, masyarakat (bukan PKI) takut kejadian itu terus berlanjut dan akan menimpanya. Sebaliknya, orangorang dan simpatisan PKI juga kawatir akan terjadi balas dendam dari keluarga korban dan para musuh-musuhnya termasuk dari aparat pemerintah. Hal tersebut berlangsung sampai dengan tahun 1965. Dalam kondisi seperti itu, kaum wanita, terutama ibu-ibu rumah tangga berupaya menenangkan, membimbing anggota keluarganya melalui saluran pendidikan informal (keluarga) dan non formal. Dalam berkomunikasi, terutama kepada anak-anaknya, ibu-ibu mendidik untuk selalu mendekatkan diri 
kepada Allah SWT, meningkatkan ibadah dan bertawakal pada-Nya, berhati-hati bergaul, melarang keluar rumah di malam hari, dan tidak perlu takut melawan keangkaramurkaan, tetap waspada, dan menjalani hidup dan kehidupan yang tidak berbau politik. Hal tersebut sebagaimana yang dialami dan diceritakan Diyem dan Parmi.

Perilaku para wanita tersebut dikomunikasikan secara verbal maupun non-verbal. Nilai-nilai adiluhung yang dikenal di dalam masyarakat disampaikan sebagai petuah untuk perilaku berinteraksi dengan sesamanya. Diantaranya ajaran hidup atau falsafah hidup dari pujangga Ronggowarsito. Dalam ajarannya dikatakan, "Amenangi jaman edan, ewuh-ya ing pambudi, melu edan nora tahan, yen tam melu anglakoni, bojakaduman melik, kaliran wekasanipun, dilalah karsa Allah, begja-begjane kang lali, luwih begja kang eling lawan waspada" (Mengalami jaman gila, sukar-sulit dalam akal-ikhtiar, turut gila tidak tahan, kalau tak turut menjalaninya, tidak kebagian milik, kelaparan akhirnya. Takdir kehendak Allah, sebahagia-bahagianya yang lupa lebih bahagia yang sadar dan waspada).

Setelah G 30 S/PKI dapat dipadamkan oleh Orde Baru, prasangka dan stereotip sedikit demi sedikit mulai terkurangi sebagai akibat sempitnya ruang gerak PKI dan tekanan aparat yang berhasil menyudutkannya. Hubungan dengan orang-orang yang terlibat langsung atau tidak langsung dengan PKI yang dicap hitam mulai cair. Mulai cairnya hubungan tersebut atau prasangka sosial dan stereotip tidak lepas dari seringnya kontak di antara mereka. Kaum wanita juga berpartisipasi dalam proses penyadaran tentang nilai-nilai kemanusiaan yang sebelumnya terabaikan melalui kegiatan upacara adat seperti khitanan, perkawinan, dan sebagainya. Selain itu, perasaan ditekan dan disudutkan oleh Orde Baru juga memberi andil yang tidak kecil dalam proses penyadaran tersebut.

Walaupun "dikucilkan" dalam kehidupan pemerintah, ternyata tidak menghalangi mereka berinteraksi sosial, terutama para simpatisan dan anggota serta keturunan PKI. Dalam pendidikan keluarga yang dilaksanakan oleh orang tua terutama ibu-ibu melalui pengajian/pendekatan spiritual, yaitu untuk memberi maaf kepadanya. Namun demikian, sikap kewaspadaan tetap dipegang teguh. Selain itu, ada paradigma yang berkembang bahwa mereka meyakini apa yang dilaksanakan oleh pemerintah benar. Untuk itu, mereka berusaha mendidik dan atau memasukkan anaknya lingkaran pemerintah dan sekolah-sekolah pemerintah.

\section{Pembahasan}

Konsep sentral peranan wanita dalam mengatasi dampak psikologi sosial pasca Madiun Affair 1948 tertuju pada aktivitas mereka yang secara individu maupun kelompok mempunyai nilai guna dan bermanfaat bagi perilaku individu 
atau kelompok dalam mengatasi prasangka sosial dan sterotip. Dari uraian di atas tampak bahwa Madiun Affair 1948 mendistorsi dan memodifikasi hubungan sosial masyarakat desa Soco yang pada awalnya damai dan hidup rukun berubah menjadi prasangka sosial dan steretotip. Hal tersebut sangat mewarnai kehidupan masyarakat Soco sampai era 1965-an, seiring dengan berhasilnya Orde Baru menghentikan G 30 S / PKI.

Dalam interakasi sosial yang penuh dengan prasangka sosial dan sterotip, kaum wanita, terutama ibuibu rumah tangga menunjukkan kemampuan untuk mengontrol nilainilai yang hidup di masyarakat kepada orang lain terutama anakanaknya sebagai dasar dan pedoman berpola pikir dan berpola perilaku. Menurut Collins dalam Ollenburger dan Moore (2002), dalam sebagian besar masyarakat terutama di pedesaan meskipun akses untuk menguasai simbol-simbol nilai tersebut secara komprehensif, namun nilai-nilai yang dienkulturasi dan disosialisasikan dari generasi pendahulu dapat dikomunikasi secara verbal maupun non verbal.

Hal tersebut nampak pada perilaku ibu-ibu kepada anak-anak dan tetangganya untuk menjalani hidup yang penuh kepribadian psikologis yang sehat dalam arti selalu berada dalam kondisi harmonis, stabil, dan sabar dengan menyitir ajaran hidup pujangga Ronggowarsito yang tersurat dalam bait-bait Kalatida. Kalatida itu sebenarnya berisi lukisan kondisi sosial pada jamannya (abad XIX), namun demikian ajaran-ajarannya masih dipandang relevan untuk dipedomani dalam menyikapi hidup yang penuh gila-gilaan.

Saluran utama yang digunakan kaum wanita dalam mengurangi prasangka sosial dan sterotip adalah pendidikan dalam keluarga. Aktivitas ini signifikan hasilnya dan berjalan dengan baik, dikarenakan kaum wanita, khususnya ibu-ibu memliki kepribadian berbaik hati, senang mengasuh, suka berkeja kera, dan peka terhadap perasaan orang lain.

Subtansi atau materi religius yang digunakan oleh kaum wanita dalam mengatasi dampak psikologi sosial di atas dapat berjalan efektif tidak lepas dari kodrati hidup manusia. Biasanya manusia akan ingat dan mendekatkan diri kepada Tuhan apabila mengalami kesusahan atau situasi yang tidak menyenangkan. Hal tersebut sejalan dengan pernyataan Siagian (1986). Ia mengatakan, bahwa dalam keadaan kacau dan ketakutan mendorong manusia mencari asas hidup dan mendekatkan diri kepada Tuhan sebagai kekuatan moral.

Semakin mencairnya prasangka sosial dan sterotip di masyarakat Soco selain intensif kontak diantara mereka, terutama dalam urusanurusan yang menyangkut kehidupan bermasyarakat, juga tidak lepas dari perkembangan politik nasional, terutama didaftarhitamkannya orangorang PKI oleh Pemerintah Orde Baru. 


\section{Kesimpulan}

Madiun Affair 1948 memodifikasi dan mendistorsi interaksi sosial masyarakat Soco yang hidup rukun dan saling menghargai berupah menjadi interaksi sosial yang penuh prasangka sosial dan sterotip. Dalam keadaan dan situasi seperti itu, kaum wanita, terutama ibu-ibu memainkan peranan penting dalam mengatasi dampak psikologi sosial pasca Madiun Affair 1948.

Kaum wanita mempunyai kemampuan untuk mengkontrol nilainilai dan mengkomunikasikan secara verbal maupun non verbal. Walaupun tidak banyak ibu-ibu yang tidak dapat mengakses simbol-simbol nilai-nilai yang berlaku di masyarakat secara komprehensif, namun simbol-simbol nilai adiluhung terutama ajaran hidup dan kepribadian psikologis yang sehat dalam arti selalu berada dalam kondisi harmonis, stabil, dan sabar. Menyitir ajaran hidup pujangga Ronggowarsito yang tersurat dalam bait-bait Kalatida, mereka melakukan enkulturasikan dan sosialisasi kepada anggota keluarga terutama anak-anaknya dan tetangganya melalui petuah pendidikan keluarga. Dengan semakin intensif kontak diantara mereka dalam memenuhi kebutuhan hidup dan perkembangan politik nasional juga memberi andil dalam mengeliminasi prasangka sosial dan sterotip di Soco.

\section{Saran}

Mengingat banyak para pelaku dan saksi kunci yang sudah meninggal, maka peneliti harapkan ada penelitian lanjutan dengan memperluas kesaksian sehingga dapat dihasilkan hasil yang baik. Terlepas dari kekurangan dari hasil penelitian ini, peneliti berharap kita dapat mengambil nilainya guna menjalani hidup di masa yang akan datang. 


\section{Daftar Pustaka}

Arbi Sanit. 2000. Badai Revolusi Sketsa Politik PKI di Jawa Tengah dan Jawa Timur. Yogyakarta: Pustaka Pelajar.

Arief Soekowinoto. 1991. Kresek Pusat Korban Pemberontakan PKI Tahun 1948 di Madiun. Madiun: Pemda Tk II Kabupaten Madiun.

Anderson, David Charles. 2003. Peristiwa Madiun 1948 Kudeta atau Konflik Intelektual Tentara? Yogyakarta: Media Pressindo.

I Gde Widja. 1988. Pengantar Ilmu Sejarah. Semarang: Satya Wacana.

Kuntowijoyo. 2003. Metodologi Sejarah. Yogyakarta: Tiara Wacana.

Luh Putu Sendratari. 1992. Wanita Dalam Dimensi sejarah Implikasi Dalam Pendidikan Sejarah dalam Aneka Widya. Singaraja: FKIP Universitas Udayana.

Mansour Fakih. 2003. Analisis Gender Dan Tranformasi Sosial. Yogyakarta: Pustaka Pelajar 2003. Partisipasi Politik Wanita Minang Dalam sistem Masyarakat Matrilineal. Padang : LP2EM.

Milles, Matthew B. dan A. Michael Huberman. 1992. Analisis Data Kualitatif. Jakarta: UI Press.

Mulyadi Guntur Waseso. 1986. Dimensi-dimensi Psikologi Sosial. Yogyakarta: Hanindita.

Ollenburger, Jane C. dan Helen A. Moore. 2002. Sosiologi Wanita. Jakarta: Rineka Cipta.
Paulus Tangdilintin. 1991. "Peranan Wanita Konsep Kunci Yang Masih Perlu Definisi" dalam Antarwidya Nomor 3 Tahun 1 Jakarta: PAU-IS-UI.

Rochiati Wiriaatmadja. 2001. "Historiografi Wanita Yang Terabaikan: Studi Kasus di Jurusan Pendidikan Sejarah FPIPS UPI" dalam Historia No. 4 Vol. II Desember 2001. Bandung: Jurusan Pendidikan Sejarah UPI.

Samsudin. 2004. Mengapa G30S/PKI Gagal? (Suatu Analisis). Jakarta: Yayasan Obor Indonesia.

Sarlito Wirawan Sarwono. 2002. Psikologi Sosial Individu dan Teori-teori Psikologi Sosial. Jakarta: Balai Pustaka.

Siagian, Seno Harbangan. 1986. Agama-agama di Indonesia. Semarang: Satya Wacana.

Tim Jawa Pos. 1990. Lubang-lubang Pembantaian Petualang PKI Di Madiun. Jakarta: Grafiti.

Thompson, John B. 2004. Kritik Ideologi Global Teori Sosial Kritis Tentang Relasi Ideologi Dan Komunikasi Massa. Yogyakarta: IRCiSoD.

W. A. Gerungan. 1991. Psikologi Sosial. Bandung: PT Eresco. 